This item was submitted to Loughborough's Research Repository by the author.

Items in Figshare are protected by copyright, with all rights reserved, unless otherwise indicated.

\title{
Where to now? Future directions for anarchist research
}

PLEASE CITE THE PUBLISHED VERSION

http://www.continuumbooks.com/

PUBLISHER

(c) Continuum

VERSION

AM (Accepted Manuscript)

LICENCE

CC BY-NC-ND 4.0

REPOSITORY RECORD

Kinna, Ruth. 2019. "Where to Now? Future Directions for Anarchist Research". figshare.

https://hdl.handle.net/2134/10171. 
This item was submitted to Loughborough's Institutional Repository (https://dspace.lboro.ac.uk/) by the author and is made available under the following Creative Commons Licence conditions.

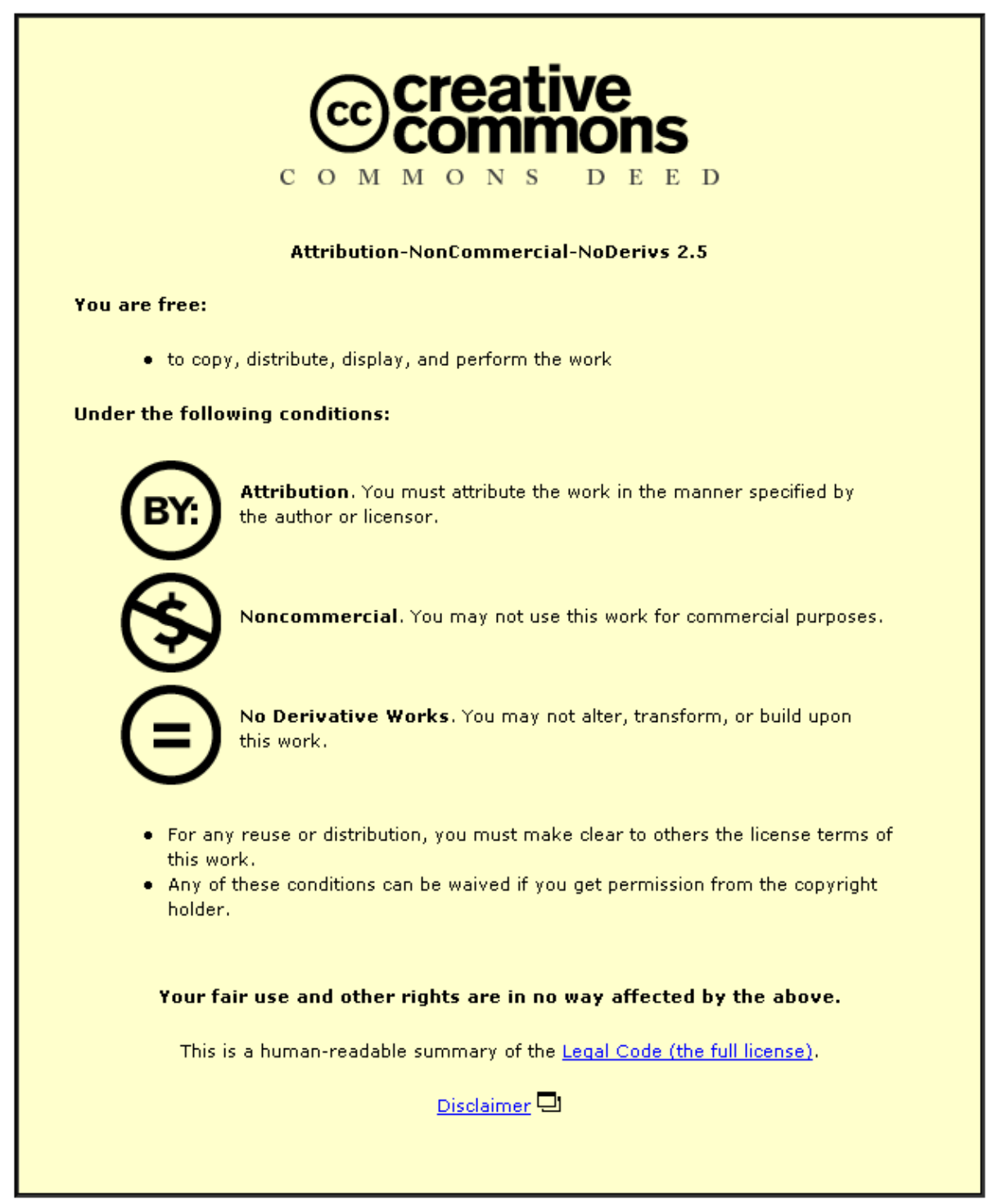

For the full text of this licence, please go to: http://creativecommons.org/licenses/by-nc-nd/2.5/ 


\title{
16 Where to Now? Anarchist Research
}

\author{
Ruth Kinna
}

In which directions do these rich and diverse essays orientate future research? More specifically, if debates about the relationship of current research to historical traditions point towards a general commitment to the celebration of anarchism's heterodoxy, what avenues might researchers explore in further probing anarchist practices? While any attempt to answer this question definitively is foolish, the essays indicate some possible avenues for further exploration. One line of inquiry is theoretical and concerns the ways in which researchers conceptualize or re-conceptualize key concepts, central to anarchist traditions, in the light of current practices and ideas. A second is connected with aims, purposes, goals that underpin the relationship between the ends and means of anarchist practices. A third is about ideology and the tensions beteen the desire to delineate a distinctively anarchist politics in ways that avoid reification.

\section{Theorizing Anarchy}

An important theme explored in a number of essays (e.g. Motta, Jeppesen and Nazar and Evren) is the relationship between anarchism and other currents of anti-authoritarian and anti-oppression politics - the tensions between anarchist and non-anarchist groups; the potential to cooperate and find commonality through participation in or experience of shared activities and the mutual reflection that flows - or not - from discussion, dialogue, skill-sharing and learning supported by interactivity. These relationships raise questions about the ways in which political demands are 'translated' from one context to another, as Motta argues, and about the extent to which particular concepts or ideas can be generalized: This is one of the issues that Evren's work raises. Because anarchist ideas tend to be interpreted through the conceptual lenses of antagonistic traditions, finding alternatives is difficult and the rhetorical flourish of canonical thinkers, encouraging uncharacteristically absolutist claims about anarchist commitments to a variety of principles and goals, adds another 
layer of difficulty. ${ }^{1}$ Yet there is a tradition of conceptual thought into which anarchist analyses of work ${ }^{2}$ and meta-concepts like time, fit. And there is scope to investigate familiar concepts and to reflect on their normative values and political implications, using a range of methodological approaches and literatures. Indeed, the subversive affinities ${ }^{3}$ which Evren and Antliff point to and the intersectional oppressions that Jeppesen and Nazar discuss provide a new impetus for such projects. ${ }^{4}$ While the idea that researchers might be encouraged to rethink concepts of law, nation, state, authority, promising, religion ${ }^{5}$ or property - to name some of the prickliest - is highly contentious and potentially deeply divisive, the failure to do so while attempting to find commonality with, for example, landless peoples' movements for which issues of land ownership and sovereignty in respect of local resources are sometimes central, makes little sense.

The tendency to assess anarchist practices by the standards of non-anarchist conventions and expectations also leaves space for further work. For example, probing decision-making practices and showing how these contribute to an understanding of processes which challenge liberal conceptions of democracy, helps meet the objections of critics eager to point out the failure of anarchists to find a solution to the problem of power in the state. Theorizing alternatives in relation to practice also helps remove the evaluation of those practices from the frameworks of success and failure that typically undercut anarchist ideas. Indeed, the reluctance to scrutinize concepts like mutual aid or to consider its limits (in eradicating ordinary conflicts or disagreements, emotional pain or hurt), plays into the hands of those who want to suggest that anarchy is a perfectly desirable but utterly impossible condition. According to one recent analysis of solidarity, anarchism has nothing whatsoever to contribute to the concept's eonceptualization. And it is the failure of anarchists to achieve power that renders the anarchist contribution irrelevant. ${ }^{6}$ This claim certainly points to a gap in the literature.

The role for political theory is not defined merely reactively, however. One of the striking images of anarchy to emerge from Newman's and Prichard's work - both of whom draw on a war model - is one of creative and productive tension, based on the dynamic and fluid balancing of social forces. The idea of affinity discussed by Antliff similarly rejects institutional permanence as an aspiration but suggests that forces are able to develop in relation to each other because memberships of social groups are cross-cutting. In this model, no group becomes hegemonic and the potential for antagonism is reduced. But it is not eradicated, and in Newman's and Prichard's models, nor will it ever be. The image of anarchy they capture not only provides a context to examine the ways in which familiar concepts might be (re)conceptualized, but, above all, a framework to discuss the implications of plurality. ${ }^{7}$ The implications are challenging. For example, Davis argues that there are different ways in which 
'revolution' might be usefully understood. In particular, he mentions the ways in which arguments about violence cloud debate and discusses the necessity of defending judgements about the rightness and wrongness of specific actions in changeable contexts. These are undoubtedly important topics, but the issues raised by the models that Prichard and Newman present direct the debate in different ways: towards the examination of the monopolization of violence, the normalization of conflict, the potential for forging alliances between disparate groups and of accommodating ideological difference. How might these draw on models of transient movement such as that Purkis outlines or on notions of commonality and community in militant action and the practices of active listening, compassion and mutual respect which Jeppesen and Nazar discuss? To return to the example of decision-making, which Davis also raises, the dynamics of anarchy raise other interesting questions about the aspirations for consensus decision-making, the principles supporting consensus where it operates, and the extent to which and on whom the decisions made by consensus are binding. Specifically, where individuals are not expected ever to bind themselves to collective decisions, how is the trust on which solidarity depends forged? And if consensus does not invite assent and relies instead on opting out - blocking and veto - how are individuals protected from the coercive pressures of solidarity to endorse a decision that they might not actually support?

\section{Aims, Goals and Purposes}

A second theme emerging from the contributions to this volume is how anarchist approaches to research might contribute to changing the world in practical and creative ways. The concern to develop research practices consistent with an anarchist desire for re-enchantment is a strong strand in Purkis's sociology. Likewise, the need to shape programmes of radical reform in existing communities is the thrust of Price's analysis of social ecology and of Cook's and Norcup's discussion of anarchist geographies. These discussions raise a number of interrelated questions about the meaning of revolution, radicalism and reform; the status of anarchist ideals in theory and practice and the relationship between means and ends of anarchist actions and the ethics of change. All these different ideas touch on the concept of prefiguration which, as Davis rightly notes, has become a central concept in anarchist thinking.

The idea of prefiguration is sometimes traced to the historical rejection of the means-ends relationship defended in some forms of non-anarchist socialism. This is usually expressed as a rejection of the claim that revolutionaries might seize control of the instruments of repression and deploy them to secure liberation and the concomitant rejection of parliamentary politics. But it has a number of aspects: an objection to the idea of socialism that this strategy 
implies (a classless society in which authoritarianism and/or industrial technologies remain unchallenged); the Machiavellian and dictatorial politics that it sanctions ${ }^{8}$ and the theoretical certainties that justify the adoption of vanguard strategies. In current discourse, and perhaps because of the way various waves of new anarchists have extended the historical rejection of means-ends distinctions, it now has slightly different connotations. Prefiguration might describe the building of a new world in the heart of the old. In this way, it is defined in its ordinary sense to mean a foreshadowing: the construction of the future in the present. In addition, prefiguration can describe the process through which revolutionary aspirations are expressed. Both assume an intimate relationship between action and change and a commitment to direct action. But while the first relationship typically finds purpose in formulating principles of action, while rejecting strategies that benchmark the rightness of actions against the realization of a future goal, the second usually prioritises a commitment to the display of anarchist social relations. Contextualized by arguments about the anarchist past, discussions of prefiguration tend to point to two alternative strategies: class struggle and revolutionary exodus, to use Davis's terms. However, the principle of prefigurative politics facilitates the discussion of political and ethical questions, as well as highlighting these strategic differences.

In the first case, the puzzle is to negotiate the gap between the potential for change and the urgency of its achievement. This might be expressed in terms of the relationship between reform and revolution. ${ }^{9}$ It might also be examined with reference to concepts of 'protest' and 'resistance' and the contexts and conditions in which these forms of action operate, are encouraged and are transformed. Alternatively, it might be understood in terms of minimal and maximal programmes, as Price recommends in his analysis of Bookchin. His analysis paves the way for the examination of a particular set of issues: the extent to which alternative organizations and social practices can be practically developed in the body of capitalism. There are clearly overlaps between these approaches. Indeed, Cook and Norcup's work suggests that they can and should be drawn together and that community-building projects provide valuable sites for their joint development. As they argue, their idea is not a new one. It draws on traditions that extend back to Ward and Kropotkin. Yet the ability to combine them might be further exploited, because the danger of associating reform and revolution on the one hand, and minimal and maximal programmes on the other, with particular revolutionary strategies, is that the transformative potential of particular actions becomes overinflated while proposals for workable change remain sidelined or unappreciated.

The political aspect of the conundrum is to work out how the futures which anarchist actions are designed to prefigure can escape the present: how the future might be imagined in ways that are not constraining or, as Antliff describes, totalizing and deterministic. The rejection of utopian thinking, too 
often hung on the strange creatures dredged up from the anarchist past, is sometimes presented as a reason not to think about this question. But this sort of oppositional thinking is too blunt. As Motta argues with respect to post-left anarchy, there is a positive value in thinking about how to move 'from here to there', for without any bridge, 'we are left with a pure free "us" and an alienated limbless "other." ' How then might research probe ideas of utopia and utopianism positively to think about different futures? How might images or ideas of possible futures help open up a dialogue about the content of anarchist politics and the relationship between anarchism and the anarchistic? What sort of qualitative choices might anarchist practices imply? Anarchist literatures frequently nod to the social benefits and political feasibility of anarchy, but there are still large gaps in the discussion of its potential costs and the implications of anarchist organizing for daily living - which are likely to be very different across the world and for different groups and individuals.

The third aspect of the conundrum encourages reflection on the principles of action: the extent to which prefigurative behaviours can or should follow what Max Weber called an ethics of responsibility, which links political action to the consideration of potential outcomes, and the ethics of ultimate ends which instead orients conduct towards the fulfilment of personal values, stressing the intimate relationship between autonomously chosen goals and individual behaviours. This distinction, which owes a considerable debt to Weber's engagement with anarchists - particularly Tolstoyan anarchism - is usually thought to be unbridgeable..$^{10}$ However, Antiff's discussion of Emma Goldman suggests that there is some overlap and that the relationship between responsibility and ultimate ends is both possible and constructive. Yet in contemporary anarchism, division seems to have been the rule, most obviously felt in arguments about social and lifestyle anarchism, which are often unhelpfully mapped to additional dichotomies: individualism versus socialism, violence versus non-violence, egoism versus community and anti-organization versus organization. Given the ferocity of this argument, further work might usefully reflect on the depth of the gap between responsibility and conviction; try to unpack the links between these two outlooks and the complex political commitments, philosophical values and moral principles that both might support. ${ }^{11}$

The strategic, political and ethical aspects of prefiguration are not easily disentangled in practice, but there is a practical purpose in thinking about the implications of prefigurative politics. Adopting strategies that reject the visions on which their realization depends is counterproductive. Exaggerating claims about the revolutionary potential of particular experiments is equally so. The components of prefiguration might be bolted together in different ways, but the principles of any construction should be transparent. As Antliff argues, the idea of personal liberation is attractive to many anarchists: Emma Goldman's Living My Life is often cited as an inspiring example which others might follow. 
The assertiveness of the un-man described by Stirner has a similar appeal. Yet this concept of prefigurative politics, that individual behaviours adopted in the present are themselves transformative, might be adopted either as part of an ethics of ultimate ends or as one of responsibility. To assess the actions of individuals by one standard or the other courts potential misunderstanding, and distortion. Similarly, to treat individual failures to adopt particular behaviours as a lack of personal virtue or indication of weak commitment to a shared vision (whether or not it is articulated) risks demotivation and reduces the potential for empowerment. ${ }^{12}$ By the same token, it encourages public demonstrations of virtue, not quite on the model of Robespierre, but sometimes purist and unforgiving. One question for research, then, is how this conception of prefigurative change might strengthen the latter dynamically and minimize the former, to promote conceptions of liberation that do not collapse in on themselves, weighed down by assumptions about effective or virtuous behaviour, universal assent and/or capability.

\section{Ideology and Self-Understanding}

Boundary disputes in anarchism have a long and angry history and one that does not seem to diminish in importance or temper over time. The reason has a lot to do with the rearguard action anarchists have been forced to fight in order to establish, as Alexender Berkman explained, 'what anarchism is not'. It is also connected with the oft-made charge that anarchism lacks a political theory; a charge based on interpretations that are too often decontextualized or on confusions resulting from the way in which the label is (and has been) applied to a wide variety of political doctrines. On a traditional left-right axis, anarchism is not only used to describe socialist currents and capitalist, market-based doctrines but also anti-left and openly hierarchical forms of anti-statism. ${ }^{13}$

If, as Evren argues, positively appraising what anarchism is (or might be) has proved problematic and the fine line between thinking creatively about a set of traditions and establishing a referential canon has been crossed, the willingness to throw out the idea of a political tradition in favour of letting a thousand anarchisms bloom is unattractive. Projects of ideological classification that move beyond abstract readings of canonical texts such as that which Franks suggests are valuable. The attempt to examine the ways in which different groups and activists have identified and grouped core and peripheral concepts and to chart the shifts and developments that have occurred in the location and meaning of these conceptual relations - over time and across cultures - provides a constructive way of thinking about boundary disputes. This approach, moreover, is less likely to demonize as non-anarchist any proposal that emerges from an oppositional current, designated as outsider for 
one reason or another. Analysing the relationship between Marxism and anarchism, for example, is more productive than dismissing any idea or individual classified within the Marxist camp. Similarly, discussing the ways in which anti-statism has been and might be understood is more fruitful than rejecting the relationship to anarchism altogether.

Acknowledging affinities, as Antliff, Goodway and Evren do in different ways, does not rule out boundary-marking but it changes the status attributed to the boundaries and process of their negotiation: in Motta's terms, it makes them permeable to border thinking. The idea of affinity opens the way to the mapping of anarchist politics in fluid ideological continuums which recognize the blurring between anarchists of different stripes, on the one hand, and all designations of capital and small ' $a$ ' anarchists (or those who prefer to be without adjectives), on the other. Being less concerned to fix the boundaries and more concerned with investigating the processes of their formation, research on this model captures the fluidity of anarchist doctrines without dissolving its parameters.

History is an essential element in this research. Reflections on the history of the movement, its experiences, ideas and manifestations not only debunk familiar, exaggerated or plainly inaccurate stereotypes but also help identify the lines of distinctively anarchist politics. History, moreover, offers a positive ways to reflect on contemporary political issues without suggesting that answers might be found in the knowledge of the past. Studying how, for example, individualist feminists applied concepts of self-ownership in discussions of childcare and maternal rights contributes to an understanding of the women's movement, delineates some of the ways in which anarchist feminists attempted to tackle patriarchy and provides a focus for thinking about current political problems. ${ }^{14}$ Similarly, as Honeywell argues, contextualizing historical anarchist debates about education, urban design, housing, crime and punishment both facilitates comparison with non-anarchist approaches and offers a critical framework for modern analysis. More broadly, as Prichard shows, understanding why anarchists did not jostle for power in the state in a particular temporal and spatial location provides a theoretical lens to examine the character of the modern European state, the principles which underpin claims to authority and the interrelationship of international and domestic politics. Notwithstanding Evren's critique of eurocentrism, the historical approach also supports useful anthropological distinctions between anarchism, pre-European state anarchist traditions and non-anarchist anarchic polities. ${ }^{15}$

Naturally, other approaches to ideology are possible. As numerous contributors point out, direct engagement with movement practices offers similar opportunities for dialogue and mutual learning. But history lends these conversations depth, and research that offers ways into the past without closing it down occupies an important place in contemporary anarchist politics. The 
extent to which blurring is embraced is a political decision. But by keeping faith with the anti-theologism of Proudhonian and Bakununist thought, anarchist histories help tease out the implications of particular choices and provide perspectives on contemporary arguments in ways that keep anarchism alive.

\section{Notes}

1. The adequacy of approaches to liberty and the practical implications of the unqualified commitment to 'absolute' freedom is the subject of Matthew Wilson's PhD thesis Rulers Without Rules: The Possibilities and Limits of Anarchism (Loughborough University, 2011). The negative consequences of treating organization-antiorganization as an opposition is exacerbated by the tendency to link the choice strongly to subcategories of anarchism, notably Platformism or class struggle anarchism (for organization) and 'individualism' and post-left anarchy (for antiorganization). Murray Bookchin's distinction between social and lifestyle anarchism operates in a similar manner: Social Anarchism or Lifestyle Anarchism: An Unbridgeable Chasm (Oakland, CA, and Edinburgh: AK Press, 1995). For an alternative approach, see Stevphen Shukaitis 'Dancing Amidst the Flames: Imagination and Self-Organization in a Minor Key', Organization, 15(5) (2008), 743-64, available at http://org.sagepub.com/content/15/5/743.full.pdf+html.

2. One of the best-known treatments is Bob Black's The Abolition of Work, online at www.inspiracy.com/black/abolition/abolitionofwork.html. See also Stevphen Shukaitis, 'The Labor of Imagination', chapter VII of Imaginal Machines: Autonomy $\mathcal{E}$ Self-Organization in the Revolutions of Everyday Life (Brooklyn, NY: Autonomedia, 2009), pp. 119-39.

3. The idea of 'subversive affinity', used to refer to border transcendence and multiplicity in struggle, is explored in a discussion of the Zapatista movement by Jakub Burkowicz, 'Subcommandante Marcos', Affinity Project, at http://affinityproject.org/ theories/marcos.html.

4. See also Richard Day's discussion 'Anarcha-Indigenism' at the Affinity Project site available at http://affinityproject.org/traditions/anarchaindigenism.html. Anarch@ Indigenism is also the subject of Glen Coulthard, Jacqueline Lasky, Adam Lewis and Vanessa Watts (eds), Affinities, 5(1) (2011), available at http://journals.sfu.ca/affinities/ index.php/affinities/issue/view/8/showToc. On Indigenous anarchism, see Aragorn, 'Locating an Indigenous Anarchism', Green Anarchy, 19 (2005), available at http:// theanarchistlibrary.org/HTML/Aragorn__Locating_An_Indigenous_Anarchism. html; Andalusia Knoll, interview with Silvia Rivera Cusicanqui, 'Indigenous Anarchism in Bolivia', available at http://uriohau.blogspot.com/2007/10/indigenousanarchism-in-bolivia.html; Ramor Ryan, 'Zapatista Spring: Anatomy of a Rebel Water Project', Perspectives, 2011, available at www.anarchiststudies.org/node/504; and presentations by Kate Milley, Tom Keefer, Shaista Patel and Missy Elliott for the panel 'Anti-Colonial Anarchism and Indigenous Resistance' at the North American Anarchist Studies Network Conference, January 2011, available at www.youtube. com/user/bridgeheadproduction\#g/c/657239ED3369E35D. A useful short introduction to Indigenous actions in North America, 'Native Resistance to "Canada" ' (April 2002) is available at www.schnews.org.uk/sotw/canada-native-resistance. $\mathrm{htm}$. An anonymous interview, 'Anarchist-Indigenous Solidarity in Ontario', published by the Affinity Project in July 2008 is available at http://affinityproject.org/ interviews/guelph1.html. Information about a range of Canada resistance struggles 


\section{The Continuum Companion to Anarchism}

can be found at 'Vancouver No One Is Illegal', available at http://noii-van.resist. ca/. For Aotearoa-NZ, see 'Neo-liberal Globalisation and the Tino Rangatiratanga movement', Thr@ll, 18 (March-April 2001), available at www.thrall.orconhosting. net.nz/18tino.html; Teanau Tuiono, 'Tino Rangatiratanga and Capitalism', Thr@ll, 24, available at www.ainfos.ca/03/mar/ainfos00200.html; 'Anarchism and Aboriginal Sovereignty', available at http://slackbastard.anarchobase.com/?p=1264; the Tino Rangatiratanga movement is discussed in Toby Boraman's The Myth of Passivity (Treason Press, 2005), available at http://libcom.org/files/The\%20Myth\%20of\%20 Passivity1.pdf; and by Anarchia, 'An Equal Society? Race and Class Divisions in Modern New Zealand Society' (2009), available at http://anarchia.wordpress. com/2009/04/11/an-equal-society-race-and-class-divisions-in-modern-new-zealandsociety/.

5. For concerns about religion and multiculturalism, see Paul Stott, 'British Islamism Toward an Anarchist Response', Shift Magazine (2011), available at http://shiftmag. co.uk/?p=407 and online with comments athttp://libcom.org/library/british-islamismtowards-anarchist-response-paul-stott.

6. Steinar Stjernø notes that 'the anarchists developed a consistent and coherent theory and practice of working-class solidarity' and that the anarchist conception compared favourably to the Leninist one. Having made this point, he ignores it 'because anarchism failed to achieve political power, almost universally, in Europe'. Solidarity in Europe: The History of an Idea (Cambridge: Cambridge University Press, 2004), pp. 57-8. I am grateful to John Nightingale for drawing my attention to this comment. For a discussion of mutual aid and hurt, see Daniel P. Jaeckle, 'Interpersonal Ethics in Ursula K. Le Guin's The Dispossessed', Anarchist Studies, 20(1) (2012), forthcoming.

7. Mike Gunderloy discusses some of these issues in 'Closing the Gaps: Challenges for the Anarchist Movement', in Gunderloy and M. Ziesing (eds), Anarchy and the End of History (Rensselaer, NY: Factsheet Five/Lysander Spooner, 1991), pp. 11-19.

8. On the influence of the Jacobin principle of political conquest in non-anarchist socialist thought, see E. B. Bax, The Last Episode of the French Revolution Being a History of Gracchus Babeuf and the Conspiracy of Equals (London: Grant Richards, 1911), pp. 136, 259, online available at www.marxists.org/archive/bax/1911/babeuf/index.htm.

9. Nicolas Walter, About Anarchism (London: Freedom Press, 2002), pp. 78-9; David Graeber interview with Seth Fiegerman, 'The Man Behind Occupy Wall Street', online at www.thestreet.com/story/11293836/1/meet-the-man-behind-occupy-wallstreet.html. Graeber commented: 'If Nancy Pelosi is suddenly inspired to put out a call for a debt jubilee, that would be great. Nobody is going to say that's bad because it's backed by a government we consider to be illegitimate. That won't change our long-term visions. As long as you are on the same path, what we are really arguing for is what's possible so there's no reason we can't work together.' Like Walter's, this model of reform and revolution maps onto an institutional-extra-parliamentary distinction.

10. S. Whimster (ed.), Max Weber and the Culture of Anarchy (Basingstoke: Palgrave Macmillan, 1999).

11. Weber suggests that the ethic of responsibility involves a distinction between means and ends and he argues that violence is the decisive means in politics. Associating anarchism (anarcho-syndicalism and Tolstoyan anarchism) with the ethic of ultimate ends, he therefore argues that this ethic is necessarily compromised by involvement in politics. However, in Weber's terms, the means-ends distinction that anarchists draw might be construed as a rejection of the monopoly of violence rather than its deployment. Moreover, decisions about violence or non-violence might be justified with reference to either ethic. Tolstoyan pacifism is sometimes grounded on considerations of its effects (an eye for an eye and the world goes blind) and at other times 
with reference to the principle of non-resistance to evil, which describes the idea of Christian virtue. Indeed, Weber acknowledges that the ethic of ultimate ends is not identical with irresponsibility and that the ethic of responsibility is not mere opportunism. The difference between the two seems to rest on the willingness of political actors to be held accountable for their actions. Weber, Politics as a Vocation, available at www.ne.jp/asahi/moriyuki/abukuma/weber/lecture/politics_vocation.html.

12. See Sheila Rowbotham's sympathetic criticism of Emma Goldman in Women, Resistance and Revolution (Harmondsworth: Penguin, 1980), p. 97.

13. A post by Zarathustra at Libcom.org usefully identifies some key figures in Anarcho-fascism and National Anarchism. http://libcom.org/forums/thought/anarcho-fascism-07022008. For an idea of what National Anarchist community-building implies, see www.youtube.com/watch?v=_ZO_JgTFB7M or American Revolutionary Vanguard at http://attackthesystem.com/ or Anarchists at www.national-anarchist. net/.

14. Wendy McElroy, Individualist Feminism of the Nineteenth Century: Collected Writings and Biographical Profiles (Jefferson, NC: MacFarland \& Co Inc, 2001).

15. H. Barclay, People without Government: An Anthropology of Anarchism (London: Kahn \& Averill/Cienfuegos Press, 1982).

\section{Bibliography}

Anarchia, 'An Equal Society? Race and Class Divisions in Modern New Zealand Society' (2009), available at http://anarchia.wordpress.com/2009/04/11/an-equal-society-raceand-class-divisions-in-modern-new-zealand-society/.

Andy at Slackbastard, 'Anarchism and Aboriginal Sovereignty', available at http://slackbastard.anarchobase.com/?p=1264.

Anon., 'Anarchist-Indigenous Solidarity in Ontario', Affinity Project, July 2008, available at http://affinityproject.org/interviews/guelph1.html.

Aragorn, 'Locating an Indigenous Anarchism', Green Anarchy, 19 (2005), available at http://theanarchistlibrary.org/HTML/Aragorn__Locating_An_Indigenous_ Anarchism.html.

Barclay, Harold, People without Government: An Anthropology of Anarchism (London: Kahn \& Averill/Cienfuegos Press, 1982).

Bax, Ernest Belfort, The Last Episode of the French Revolution Being a History of Gracchus Babeuf and the Conspiracy of Equals (London: Grant Richards, 1911), pp. 136, 259, available at www.marxists.org/archive/bax/1911/babeuf/index.htm.

Black, Bob, The Abolition of Work, available at www.inspiracy.com/black/abolition/abolitionofwork.html.

Bookchin, Murray, Social Anarchism or Lifestyle Anarchism: An Unbridgeable Chasm (Oakland, CA and Edinburgh: AK Press, 1995).

Boraman, Toby, The Myth of Passivity (Canberra: Treason Press, 2005), available at http:// libcom.org/files/The\%20Myth\%20of\%20Passivity1.pdf.

Burkowicz, Jakub, 'Subcommandante Marcos', Affinity Project, available at http://affinityproject.org/theories/marcos.html.

Coulthard, Glen, Jacqueline Lasky, Adam Lewis and Vanessa Watts, 'Anarch@Indigenism', Affinities, 5(1) (2011), available at http://journals.sfu.ca/affinities/index.php/affinities/ issue/view/8/showToc.

Day, Richard, 'Anarcha-Indigenism', available at http://affinityproject.org/traditions/ anarchaindigenism.html. 


\section{The Continuum Companion to Anarchism}

Fiegerman, Seth, interview with David Graeber, 'The Man behind Occupy Wall Street', The Street (31 October 2011), available at www.thestreet.com/story/11293836/1/meetthe-man-behind-occupy-wall-street.html.

Gunderloy, Mike, 'Closing the Gaps: Challenges for the Anarchist Movement', in Gunderloy and M. Ziesing (eds), Anarchy and the End of History (Rensselaer, NY: Factsheet Five/Lysander Spooner, 1991), pp. 11-19.

Jaeckle, Daniel P., 'Interpersonal Ethics in Ursula K. Le Guin's The Dispossessed', Anarchist Studies, 20(1) (2012), forthcoming.

Knoll, Andalusia, interview with Silvia Rivera Cusicanqui, 'Indigenous Anarchism in Bolivia', available at http://uriohau.blogspot.com/2007/10/indigenous-anarchism-inbolivia.html.

Libcom, http://libcom.org/forums/thought/anarcho-fascism-07022008.

McElroy, Wendy Individualist Feminism of the Nineteenth Century: Collected Writings and Biographical Profiles (Jefferson, NC: MacFarland \& Co Inc, 2001).

Milley, Kate, Tom Keefer, Shaista Patel and Missy Elliott, 'Anti-Colonial Anarchism and Indigenous Resistance', North American Anarchist Studies Network Conference, January 2011, available at www.youtube.com/user/ bridgeheadproduction\#g/c/657239ED3369E35D.

Rowbotham, Sheila, Women, Resistance and Revolution (Harmondsworth: Penguin, 1980).

Ryan, Ramor, 'Zapatista Spring: Anatomy of a Rebel Water Project', Perspectives (2011), available at www.anarchiststudies.org/node/504.

SchNEWS, 'Native resistance to "Canada"' (April 2002), available at www.schnews.org. uk/sotw/canada-native-resistance.htm.

Shukaitis, Stevphen, 'Dancing Amidst the Flames: Imagination and Self-Organization in a Minor Key', Organization, 15(5) (2008), 743-64, available at http://org.sagepub.com/ content/15/5/743.full.pdf+html.

-, 'The Labor of Imagination', chapter VII of Imaginal Machines: Autonomy \& SelfOrganization in the Revolutions of Everyday Life (Brooklyn, NY: Autonomedia, 2009), pp. 119-39.

Stjernø, Steinar, Solidarity in Europe: The History of an Idea (Cambridge: Cambridge University Press, 2004).

Stott, Paul, 'British Islamism - Toward an Anarchist Response', Shift Magazine, 11 (2011), available at http://shiftmag.co.uk/?p=407 and online with comments at http://libcom. org/library/british-islamism-towards-anarchist-response-paul-stott.

Thr@ll, 'Neo-liberal Globalisation and the Tino Rangatiratanga movement', Thr@ll, 18 (March-April 2001), available at www.thrall.orconhosting.net.nz/18tino.html.

Tuiono, Teanau, 'Tino Rangatiratanga and Capitalism', Thr@ll, 24, available at www.ain fos.ca/03/mar/ainfos00200.html.

Walter, Nicolas, About Anarchism (London: Freedom Press, 2002).

Weber, Max, Politics as a Vocation, available at www.ne.jp/asahi/moriyuki/abukuma/ weber/lecture/politics_vocation.html.

Whimster, Sam (ed.), Max Weber and the Culture of Anarchy (Basingstoke: Palgrave Macmillan, 1999).

Wilson, Matthew, Rulers without Rules: The Possibilities and Limits of Anarchism (PhD thesis, Loughborough University, 2011).

Zarathustra, Libcom, available at http://libcom.org/forums/thought/anarcho-fascism07022008. 